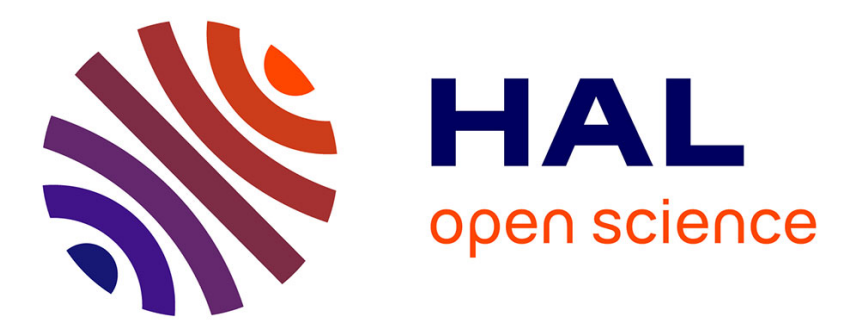

\title{
Multilingual Developing Countries Facing Globalization
}

Irène Rabenoro

\section{To cite this version:}

Irène Rabenoro. Multilingual Developing Countries Facing Globalization. Alizés: Revue angliciste de La Réunion, 1999, Languages and Education: Parameters for Multicultural South Africa, 18, pp.113-125. hal-02346456

\section{HAL Id: hal-02346456 \\ https://hal.univ-reunion.fr/hal-02346456}

Submitted on 5 Nov 2019

HAL is a multi-disciplinary open access archive for the deposit and dissemination of scientific research documents, whether they are published or not. The documents may come from teaching and research institutions in France or abroad, or from public or private research centers.
L'archive ouverte pluridisciplinaire HAL, est destinée au dépôt et à la diffusion de documents scientifiques de niveau recherche, publiés ou non, émanant des établissements d'enseignement et de recherche français ou étrangers, des laboratoires publics ou privés. 


\section{Multillingual Developing Countries Facing Globallization}

All countries are facing globalisation, which takes place

7 mostly in English. To avoid being totally left behind, developing countries and African ones in particular need to rethink their language, cultural and educational policies in the framework of their development schemes. In this line, the main purpose of this paper is to highlight the complexity of making decisions about language uses with a view to having the majority of African learners benefit from language education and education at large. For indeed, a language policy thought to be beneficial to the majority can sometimes cause exactly the reverse effect. Some suggestions as to how to reduce social inequalities resulting from language uses will be put forward.

In Africa, the privileged minority is at least bilingual in its first language and in a language of international communication - usually the former colonizers' language. The latter language contributes to perpetuating the social success of the advantaged minority of the population. As for the disadvantaged majority, it is roughly speaking monolingual or bilingual but in the local or national language and has therefore limited access to the modern sector.

Whether they are seen as threats (implementing democracy can be a condition to financial aids from western countries) or just as realities, democracy and globalisation have been the keywords in Africa in the last few years. When designing any development project, these two parameters are thus supposed to be taken into account. Yet, implementing democratic principles may imply questioning or even disrupting some aspects of an African people's culture. Whereas democracy is related to culture and hence, to the language issue since language and culture 
cannot be parted, globalisation is mainly linked with the economic issue. Given such facts, what is to become of the languages which are not of international use? More concretely, what about the disadvantaged majority which is not proficient in a language of international communication?

This paper is based on the assumption that all countries are multilingual and multicultural. Variation characterizes languages and cultures: there is no such thing as a country with just one language and one culture. When a country is said to have a single national language or a standard language - such is the case of Madagascar 1-, either language qualified as such actually has geographical and/or social varieties. A national language is here seen as the set of geographical and, where relevant, ${ }^{2}$ social varieties of a language. These varieties sharing many features, their users can understand each other to a great extent. As for a standard language, it is regarded as one of the varieties of a national language which has been granted an official status and has been standardized. How multilingualism and multiculturalism are handled implicitly or explicitly ${ }^{3}$ differs from one country to another. Some countries just act as though they were not concerned with such issues, and have no explicit language policy. The answer to the question about the future of the languages and cultures which are of limited use and consequently, about the future of their users is usually, among academics at least, that multilingualism and multiculturalism ought to be promoted and preserved. But then, great linguistic diversity hampers communication between groups of people within one country and hinders development actions. It also favours the use of a foreign language which serves as a lingua franca.

\footnotetext{
${ }^{1}$ Madagascar is one of the seven African countries (out of fifty-three) which have a single national language (Ouane 157). The Seychelles can also be viewed as having a single national language (Creole), which is an official language.

2 It seems that in general, only industrialized countries have social varieties of their national language, whereas in developing countries, geographical varieties - which are more or less related to ethnic groups - prevail.

3 Implicit or explicit language and cultural policies are here referred to.
} 


\section{Promoting and preserving multilingualism and multiculturalism}

Following UNESCO, preserving linguistic and cultural diversity is one principle most scholars agree on. Another principle adopted by UNESCO since $1951,{ }^{4}$ which is also widely accepted, is that education should be achieved as far as possible through the learners' first language. But we can notice that apart from slogans like "the danger for humanity is that it becomes unilingual and unicultural," ${ }^{5}$ no clear and precise reasons as to why languages and cultures should be preserved are provided. Therefore, here are a couple of examples which show that indeed multilingualism and multiculturalism ought to be preserved, but to a certain extent.

UNESCO made 1996 the year of tolerance. Most media in Madagascar translated "tolerance" into Malagasy by "fandeferana;" some others kept the French word because they knew the two words were not equivalent. As a matter of fact, "tolerance' and "fandeferana" do not mean exactly the same, although their meanings are related. The Malagasy word "fandeferana" refers to a kind of behaviour in everyday life which consists in avoiding conflicts between two persons or groups of people. We can consider the situation of two children, one being older than the other, quarrelling to have for instance an orange. Their mother or father is likely to tell the older child to "mandefitra" (verb related to "fandeferana"), that is to let the younger one have the orange because the other child is thought to be old enough to refrain from having it. In the same way, a driver who gives way to another one, especially in a traffic jam, is said to "mandefitra." In short, the notion of "fandeferana" refers to a certain behaviour which seeks interpersonal, social and even political harmony and is based on sensibility and kindness.

\footnotetext{
${ }^{4}$ (Ouane8-9). For a survey on UNESCO's discourse on the use of mother tongues in education, see Jacques Champion, Langage et pédagogie en France et en Afrique (Paris: Anthropos, 1986) 98-107.

${ }^{5}$ Among others, French President Jacques Chirac made such a statement as he was making an official visit to Argentina in March 1997.
} 
The notion of tolerance is worth being introduced in the Malagasy environment as well as in any other environment, and such notions as "fandeferana" should be preserved and even spread through the teaching of the languages which contain them. If such a step could be actually taken, preserving multiculturalism would not only mean respecting differences, as is usually stated in conferences or works about intercultural communication. It would imply that the world moves towards common moral values, more democratic and more human behaviour. However, there is a gap between principles and their implementation as we will see later on in this paper.

As mentioned earlier, implementing democracy may cause disruptions in the value system and culture of an African society. To take the example of Madagascar, although slavery was abolished by the French colonizers more than a century ago, ${ }^{6}$ the division of the society into castes is still perceptible through the kind of greetings that can be used: a person is greeted differently depending on whether he is the descendant of a noble, a free person or a slave. This very simple example reveals an expression of the various feudal forms which still prevail in Malagasy society, and most likely, in all African societies.

It should be recognized that there is good and bad in all cultures. Viewing traditional cultures just from the sentimental or exotic viewpoint would impede their holders' development. Culture should be viewed in a dynamic way and be closely related to education.

\section{Culture and education ${ }^{7}$}

Education is a social phenomenon. It expresses the culture resulting from the interaction between the human being and his environment. Education initiates children to their parents' culture so as to enable them to integrate into society. But it can also provide the means and the

\footnotetext{
6Slavery was abolished on 27 September 1896, just as the French started to colonize Madagascar. (cf. Rakoto 1).

7 This section of the paper is inspired by Rabenoro and Rajaonarivo: 1994.
} 
freedom to question the current culture, to change it so that it better meets the moral and economic needs of human beings at a certain point of history.

Curriculum design is crucial as far as multilingualism and multiculturalism are concerned. Defining the aims of education consists in answering the following questions, which are interrelated:

- what kind of society is to be built?

- what values are to be recognized?

- consequently, what kind of education does a country want its citizens to be provided with?

It is necessary to study the current values in a society in prospective terms so as to prepare the learners to future life situations. The learners' cultural/traditional identity needs to be made explicit so that they are capable of assessing and comparing different cultures.

The so-called traditional cultures should not be viewed as "good" in themselves just because they belong to some disadvantaged groups or to developing countries. They have to be adapted to the needs of development, considering the project of building a democratic society as well as the inescapable context of globalisation.

\section{From principles to implementation}

Languages and cultures are far from being equal since countries as well as individuals are not equal. In African countries, which for the most part were once colonies, several languages are in use, but competition between them is most unfair. The former colonizers' language usually dominates all the others: what are now languages of international communication - such as English and French - are still and by far the main tools of social promotion. The privileged minority which has good command of them has far greater opportunities for social and geographical mobility (e.g. getting a job in the modern sector, travelling, attending international conferences, etc.) than the disadvantaged majority which only knows the national and/or local language(s). Whereas in developed 
countries such as Britain or the United States, the focus can be on linguistic minorities, the main concern in developing countries ought to be how to empower the disadvantaged majority of the population through language and cultural actions. A realistic approach has thus to be adopted.

Supposing enough financial means (for transcribing non-written languages, for designing textbooks, reference books, etc.) and human resources (enough appropriately trained teachers) were available, the will to make a wide use of local or national languages in the various sectors of national life as well as in education does not suffice. As David Crystal points out:

Without a strong power-base, whether political, military or economic, no language can make progress as an international medium of communication. Language has no independent existence, .... Language exists only in the brains and mouths and ears and hands and eyes of its users. When they succeed, on the international stage, their language succeeds. When they fail, their language fails. (Crystal 5)

However, the economic factor is the most important of all:

... international language dominance is not solely the result of military might. It may take a militarily powerful nation to establish a language, but it takes an economically powerful one to maintain and expand it. (Crystal 7-8).

That is how English came to be the first language of international communication. A Malagasy peasant who does not even suspect that "on" and "off" are English words intuitively knows what they mean just because that is what is written on radio sets.

Nationalist, ethnic, humanistic or any other feelings will not overcome the reality of a few languages dominating in the world. Besides, people will defend their language and culture only if they know the benefits they can derive from it, and their language and culture will be preserved and spread only if their users are in a political and economic position to do so. Unless the international economic order changes, there is no reason to hope the linguistic and cultural order will really change. 
But there are other factors which have to be considered: English has the advantage of being more flexible and tolerant than other languages of international communication, namely French. It is therefore more accessible to the majority. Malagasy students tend to turn to English probably because they find it easier to learn than French but also because it does not bear a colonial connotation. Above all, they are less socially penalized when they make 'mistakes' in English than in French.

Attitudes and motivations towards such or such language have to be taken into consideration: people cannot be cheated. They are aware of a language being or not a tool for social promotion, of language as an instrument as well as an expression of power. People know which language(s) they need to be competent in, namely those that are mainly used by the major media, political figures, business people, scientists, well-off people, religious personalities, etc. In this line, John Edwards quotes African American parents:

Black parents don't want black studies or multicultural education for their children-that is for white children; black pupils need to be good at science, history, geography-at what society thinks of as things of worth. (189)

Ordinary people have a clear idea of what can help their children to succeed, although one may object to their viewpoint. For indeed, only very few children of a disadvantaged background can actually compete with the minority of privileged children who are bi- or multilingual in languages of wide use. People's attitudes and motivations cannot be changed just out of will: promoting several languages means not only including them in education as media of teaching or as compulsory subjects, but also having them used by the media, in writing, in public activities, in cultural and scientific activities, etc. Only in that prospect would their users rely on the value of these languages.

Hints at the question of feasibility from every point of view of a project aiming to spread local or national languages and cultures have been previously made. At country level, elites usually decide on behalf of the population, whether they are in competition for power or not. When intellectually enthusiastic about a project, its implementability is often neglected by its designers. Although each country has its specificities, 
lessons ought to be drawn from the experiences of many countries about making of a national or local language the medium of instruction. As to whether adopting a national or regional language as an instrument of teaching has proved to be a success or a failure seems to be controversial. ${ }^{8}$

To take the example of Madagascar, roughly speaking, the Malagasy language was used as the only medium of instruction in primary and secondary schools from 1973 to 1991, after a popular movement which overthrew the so-called neo-colonial regime claimed it in 1972. In 1991, a second popular post-independence movement, so-called for democracy, claimed the return to French as the language of teaching. Exactly the reverse of the 1972 claim. In an article about language policy in Madagascar a colleague and I published in 1997, we suggested standard Malagasy be the medium of instruction in state schools up to a level in which its use has been proved to be more efficient than that of standard French. Our aim is really to limit the damage caused to learners by these sudden and brutal switches from one language to another on the one hand; on the other hand, as teachers of English and German, my colleague and I - and many other colleagues as well of course - have realized our students definitely think in their first language. There is then no use acting as though French were their mother-tongue. For as efficient a teaching as possible, explicit reference to the Malagasy language has to be constantly made.

When it comes to the choice of the language(s) to be used as a medium or media of instruction, it can be noticed that some developed countries do make an effort to use the immigrants' languages, but most of the time, they just ignore the social and/or geographical varieties of the standard language. Multilingualism and multiculturalism are somehow slogans. Putting them into practice is quite another matter.

The conclusion which can be drawn is that making decisions about the uses of languages, that is designing a language policy, requires previous technical work. As Mohammed Hassan Abdulaziz said in an

${ }^{8}$ See among others Adama Ouane. Also, Lettre d'information de l'Association pour le Développement de l'éducation en Afrique, as well as Perissinotto. 
article of his about the history of language policies in Africa related to the choice of the medium of learning, ${ }^{9}$ very few language policies seem to be successful in Africa because they have not been designed in an objective and rational way, but guided by political reasons.

As far as teacher education is concerned, teachers ought to be provided with a body of knowledge which allows them to present the learners some way or another with a critical view of the linguistic and cultural situation in their country and in the world as linked with the political and economic implications of language learning. Although "English ... plays an important role in the reproduction of global inequalities" (Pennycook 54), we have to know that instrument of power and inequality whatever our feelings. One of the possible ways of bridging the gap between the westernised minority and the disadvantaged majority is to include in the teaching of international languages and in any educational and cultural action what can be grossly called "international usages." They refer to all kinds of behaviours, including language ones.

\section{Bridging the gap between the privileged minority and the disadvantaged majority}

It is assumed that despite differences in western cultures, there are mainstream usages which have become international standards. These standards remain to be determined and discussed, but here are a few examples which give an idea of what is meant.

\section{Example 1:}

Most Malagasy people say "Mr Smith John" instead of "Mr John Smith." The reason for this is that traditionally, Malagasy people only have one name, and they are called by one part of that single name or by really

\footnotetext{
9 "Très peu de politiques linguistiques, si tant est qu'elles existent, semblent fonctionner en Afrique. C'est parce que la plupart d'entre elles ne sont pas pensées d'une manière objective et rationnelle, mais plutôt guidées par des raisons politiques" (Abdulaziz 172).
} 
another name. It was only since French colonizers required a family name and a first name that many people - but not all - have a family name and a first name. Even people who have lived and/or studied in a western country are used to putting the family name before the first name. And yet, the dominant way is that you do not say for example "Mr Blair Tony" but "Mr Tony Blair."

Example 2:

Also due to French colonizers is the fact that since Malagasy family names can be very long (up to twenty-five letters long or more), it is hard for foreigners who do not know what they mean to pronounce them. Hence, foreigners in Madagascar and French people in particular, as well as quite a few Malagasy people imitating them, tend to call people by their first names: "Monsieur Jean" or "Madame Sahondra," which is quite rude according to western standards. We may well imagine reactions to someone addressing British Prime Minister Tony Blair as "Mr Tony" or French President Jacques Chirac as "Monsieur Jacques." Strangely enough, successive Malagasy presidents have never been called "Monsieur Philibert" (for late President Philibert Tsiranana), or "Monsieur Albert" (for former President Albert Zafy), or "Monsieur Didier" (for President Didier Ratsiraka).

\section{Example 3:}

Learners, even those who do not take English lessons, should know that "8/5/98" is read August the fifth in American English but the eighth of May in British English and in other European languages. It is needless to point out the kind of problems the fact of not knowing this peculiar American way may entail. This example cannot be said to be an international standard usage, but considering the influence of the United States over the world, it should be widely known. 
Example 4:

This example concerns telephone conversations. In Madagascar, except for the few who have lived in developed countries, people do not generally know how and when to use the phone. It is generally thought that one cannot ask for information on the phone: asking the price of goods, requesting information from an administrative employee, etc. are seen as inadequate. The very function of the phone as a quick way of conveying or receiving information is unknown and somehow not accepted by many people. What is more is that instead of going straight to the point, a telephone user would behave the way he would if he met his interlocutor, that is he would ask how his interlocutor's family is, what the news is, etc. As a result, what seems quite impolite to people who are used to the phone is rather normal to some others. For instance, when someone phones, he will say "Who's speaking? Where are you who answer the phone?", which is most annoying for somebody who is used to the mainstream ways.

\section{Example 5:}

In industrialized countries, when there is a yellow line on the floor, for instance in an airport or a railway station, it means one cannot go beyond that yellow line until the persons in front going through the customs or buying a ticket have gone. People from developing countries who do not know this usage may be blamed by the officers concerned if they do not observe this supposedly well-known rule.

There are quite a few such international usages which are taken for granted by people in industrialized countries and by the westernised minority in poor countries. What has become reflexes in some people is unfamiliar to large disadvantaged groups. It would therefore help these groups to be acquainted with such behaviours and usages through the learning of a language of international communication, through the media, education and any cultural action. 
There is a last issue which is worth being addressed: among the seven African countries with a single national language are Rwanda and Burundi. Their current acute ethnic conflicts contradict the generally accepted viewpoint according to which language, culture and ethnicity are closely related. The case of Rwanda and Burundi obviously deserves particular attention from researchers as a one and only national language is supposed to facilitate and strengthen a nation's unity.

Should explanations about the serious troubles Rwanda and Burundi are going through be found, alternative ways of viewing multilingualism and multiculturalism could be explored.

Pr Irène RABENORO 10

\section{BIBLIOGRAPHY}

Abdulaziz, Mohammed Hassan. "Histoire de la politique linguistique en Afrique concernant le choix de la langue d'enseignement," Vers une culture multilingue de l'éducation, Adama OUANE, ed. (Hambourg: Institut de l'UNESCO pour l'Education, 1995).

Batley, Edward, Candelier, Michel, Hermann-Brennecke, Gisela, Szepe, György. Les politiques linguistiques dans le monde pour le 21ème siècle, Rapport pour l'UNESCO (Fédération Internationale des Professeurs de Langues Vivantes, Août 1993).

Champion, Jacques. Langage et pédagogie en France et en Afrique (Paris: Anthropos, 1986).

Crystal, David. English as a Global Language (Cambridge University Press, 1997).

Edwards, John. Multilingualism (Penguin Books, 1995).

Landsheere, Gilbert and Viviane (de). Définir les objectifs de l'éducation (Paris: PUF, 1992).

10 University of Antananarivo, ( Madagascar). 
Lettre d'Information de l'Association pour le Développement de I'Education en Afrique / Newsletter of the Association for the Development of Education in Africa, vol. 8, $n^{\circ}$ 4, Oct.-Dec. 1996.

Ouane, Adama, ed. Vers une culture multilingue de l'éducation (Hambourg: Institut de l'UNESCO pour l'Education, 1995).

Perossinotto, Giorgio, ed. The LMRI News (University of California Linguistic Minority Research Institute), vol. 7, n 7, May-June 1998,

Rabenoro, Irène, and Rajaonarivo, Suzy. "A l'aube du 21e siècle, quelle politique linguistique pour Madagascar ?," Mots. Les langages du politique (Paris: Presses de la Fondation Nationale des Sciences Politiques avec le concours de l'Ecole Normale Supérieure de Fontenay/Saint-Cloud et du CNRS, $n^{\circ}$ 52, septembre 1997).

"Curriculum et enseignement des langues," Bulletin de l'Académie Nationale des Arts, des Lettres et des Sciences, Antananarivo, tome 7/1, 1994, 1997.

Rakoto, Ignace. ed. Actes du Colloque International sur l'Esclavage (Antananarivo: Institut de Civilisations - Musée d'Art et d'Archéologie, 1997).

Tollefson, James W. Power and Inequality in Language Education (Cambridge University Press, 1995). 